\title{
Why do doctors kill themselves? A brief communication
}

\author{
Modesto Leite Rolim Neto' (iD, Nádia Nara Rolim Lima² (iD) \\ 1Productivity Scholarship at the Faculty of Medicine of Juazeiro do Norte - FMJ / ESTACIO, Juazeiro do Norte, Ceará, Brazil. \\ ${ }^{2}$ Neuro-Psychiatry Program. Federal University of Pernambuco - UFPE, Recife, Pernambuco, Brazil.
}

\section{$凶$}

Modesto Leite Rolim Neto Faculty of Medicine of Juazeiro do Norte - FMJ / ESTACIO, Juazeiro do Norte, Ceará, Brazil.

modestorolim@yahoo.com.br

\section{Edited by:}

Juliana Ramos de Andrade
Keywords:

Doctors

Suffering

Suicide

\begin{abstract}
Background: Current evidence highlights that although it is a universal disease, depression and mental and behavioral disorders affect different careers differently. In this clinical context, studies consider that it is vitally important that we take action now to fully understand the actual impact of suicide on physician workforce.

Objective: Here we show that the suicide rate among physicians has exploded in recent decades. The suicide rate among male and female physicians is 1.41 and 2.27 times higher than that of the general male and female population, respectively.

Results: Suicide in doctors can be affected by intense competition. Other contributors include financial pressures, as well as the need to adjust to being "average" among their high achieving cohorts. Moving frequently between hospitals and wards on placement can generate anxiety too. There can be additional pressure to author publications and other CV-building achievements from early on in medical school.

Conclusion: Despite the fact that 10-20\% of them have suffered from depression, and suicide rates are reported to be much higher than among other professional groups or the general population, doctors have poor access to mental health care. The idea of giving up life comes when worries, fatigue, and emotional pain pile up on a level that makes doctors feel incapable of bearing that suffering.
\end{abstract}


$\mathrm{C}$ hanges made to the way hospitals and medical centers operate in recent years may have improved the efficiency of the American healthcare system, but at the cost of longer and more ex-haustive work schedules for doctors. Doctors are now spending less time with patients in traditional care settings and more time fulfilling extraneous tasks traditionally performed by adjunct staff and employees. As a result, the suicide rate among physicians has exploded in recent decades. The sui-cide rate among male and female physicians is 1.41 and 2.27 times higher than that of the general male and female population, respectively. ${ }^{\text {? }}$

It is vitally important that we take action now to fully understand the actual impact of suicide on our physician workforce. ${ }^{2}$ Doctors are beginning to be more confident in role modelling their vulnerability, and discussing or writing about their own mental health issues in a brave and honest way. Like seasoned clinicians, students are vulnerable to stresses inside and outside of medicine and to feelings elicited by patients who trigger strong emotional responses in us. They can be affected by the uncertainty and powerlessness that complex clinical practice can engender. In addition, medical students are subject to other stressors arising from their specific circumstances. Particularly in big cities and large medical schools, some report feeling anonymous and not always feeling like they belong or are valued. Many talk about isolation and feeling superfluous, especially in clinical placements where they may perceive themselves as spare parts. Students enter medical school as laypeople and emerge after their apprenticeship as fledgling professionals, expected to navigate scary terrain. ${ }^{3}$

To study medicine, this is the great dream of many people all over the world. However, the level of graduation requirements and responsibilities, in addition to the increasing amount of content to be assimilated, has had a marked impact on the mental health of academics and professionals. Becoming a doctor is a challenge that has become increasingly difficult. A survey conducted at the Federal University of São Paulo showed that $38.2 \%$ of medical students had depressive symptoms. Other studies conducted in Rio de Janeiro, São Paulo, Uberlândia and Recife also demonstrated the prevalence of anxiety and depressive symptoms in this population with rates varying from $12.2 \%$ to $39 \%{ }^{4}$

They can be affected by intense competition in an assessment-driven climate where many medical schools rank students' performance. Other contributors include financial pressures, which are particularly prevalent among medical students, as well as the need to adjust to being "average" among their high achieving cohorts, having previously stood out as exceptional. Moving frequently between hospitals and wards on placement can generate anxiety too. There can be additional pressure to author publications and other CV-building achievements from early on in medical school. ${ }^{3}$ Although it is a universal disease, depression and mental and behavioral disorders affect different careers differently. In Brazil, one of the professions that is most impacted by evil is medicine. ${ }^{5}$

Researchers analyzed nearly 200 studies, involving 130,000 medical students from 43 countries, to estimate the prevalence of depression, depressive symptoms, and suicidal ideation among them. The results showed that the prevalence of depressive symptoms or depressive symptoms was $27.2 \%$, the prevalence of depressive symptoms remained relatively constant throughout the studied period (1982 to $2015, \mathrm{Cl}-95 \%,-0.2 \%$ to $0,7 \%)$, in studies that evaluated depressive symptoms before and during college, the mean absolute increase was $13.5 \%$. Prevalence estimates did not differ significantly between preclinical students and clinical students $(23.7 \%[\mathrm{Cl}-95 \%, 19.5 \%$ to $28.5 \%]$ versus $22.4 \%[\mathrm{Cl}-95 \%, 17,6 \%$ to $28.2 \%])$, the overall prevalence of suicidal ideation was $11.1 \%(\mathrm{Cl}-95 \%$, $9.0 \%$ to $13.7 \%$ ), however, the percentage of students seeking psychiatric treatment was only $15.7 \%{ }^{6}$

In this context, high suicide rates are also prevalent among medical students. Suicide is the second leading cause of death for medical students. They are three times more likely to kill themselves than their peers in the same age group. As many as 30 percent of medical students suffer from depression. The work schedules for young doctors transitioning from medical school, customarily referred to as "residents," are extremely onerous. Residents are expected to work up to 80 hours a week with single shifts that can last up to 28 hours (Table 1).' 
Tabela 1. Main findings

The BMJ opinion Like seasoned clinicians, students are vulnerable to stresses inside and outside of medicine and to feelings elicited by (2019) patients who trigger strong emotional responses in us. They can be affected by the uncertainty and powerlessness that complex clinical practice can engender. In addition, medical students are subject to other stressors arising from their specific circumstances. Particularly in big cities and large medical schools, some report feeling anonymous and not always feeling like they belong or are valued. Many talk about isolation and feeling superfluous, especially in clinical placements where they may perceive themselves as spare parts. Students enter medical school as laypeople and emerge after their apprenticeship as fledgling professionals, expected to navigate scary terrain.

World Socialist Web Depression, the primary cause of suicidal ideation, affects an estimated 12 percent of male physicians and 19.5 percent Site, (2019) of female physicians, but doctors are often hesitant to seek treatment due to the stigma associated with mental health problems.As a result, doctors have the highest suicide rate among any profession in the country: 28 to 40 per 100,000 persons compared to 12.3 per 100,000 for the general population.

The Medical journal An ingrained fear of showing weakness and burdening others is juxtaposed against a deep-seated drive to help others. of Australia - MJA, Lack of time, fear of stigma and being reported to medical authorities are other barriers - which are not irrational, (2019) given studies revealing that medical professionals hold concerns over the competency of colleagues with mental health

The Physician Philosopher, (2019) Some believe the increased rate of suicide in attending physicians is attributed to the fact that, while physicians struggle with all of the same mental illnesses as other people, because of their presumed success in the eyes of others they may have a harder time asking for help.

The Guardian, This kind of masking of pain is, sadly, typical of doctors. They learn early in their training to hold the line, to come (2018) across as stoic, to turn up ready for work come what may, and never to admit to their vulnerabilities. Despite the fact that $10-20 \%$ of them have suffered from depression, and suicide rates are reported to be much higher than among other professional groups or the general population, doctors have poor access to mental health care.

Courses like medicine deal with a lot of pressure. They are, for the most part, full-time, so they require a lot of dedication from students and have a very exhausting routine. The course ends up requiring a complete health of the student (mental and physical) and can trigger problems such as depression, bipolar disorder, dependence on alcohol and other drugs and much anxiety $(G 1,2018 a)$. Doctors suicide is the medical profession's grubby little secret. Female doctors are twice as likely as the general population to take their own lives. A US study shows their suicide rate appears higher than that of other professional groups, with young doctors at the beginning of their training being particularly vulnerable. ${ }^{7}$

In Brazil, suicide is the fourth leading cause of death among young people. Psychic factors such as excessive guilt and internal demands are associated with suicides, according to the psychoanalyst and psychiatrist at the Institute of Psychiatry $(\mathrm{IPq})$ at Hospital das Clínicas Gustavo Gil Alarcão. "Suicide is a limiting, complex act in which the person acts very violently against himself. In general, there is an oversizing of guilt, as if it were responsible for a number of things that it is not".8

For many doctors, the difficulties begin as soon as they leave medical school. Final exam results determine which graduates get first choice of the available jobs across the country, meaning the weakest are most at risk of finding themselves struggling in posts that stronger students avoided, isolated, far from home in unfamiliar towns where they have no support network. ${ }^{9}$ Sometimes, those high expectations become a frustrating reality, filled with gigantic demands and responsibilities. ${ }^{10}$

Doctors suffer from mental illness and, in fact, have high rates compared with the patients they see. One survey found $85 \%$ had experienced some kind of mental health problem. " As a doctor you can make moments significant, end fear and create hope. Depression has been a door to that realisation. The issue that plagues doctors with depression is the harsh and worsening environment. ${ }^{12}$ Patients and the public sometimes find it difficult to accept that doctors can be sick. ${ }^{9}$

Perfectionism is rife among doctors. However, the very character trait that can contribute to success can also be a downfall in others. Maladaptive perfectionism refers to individuals experiencing distress over perceived personal or family failings (often unrealistic), and is associated with anxiety, depression, perceived burdensomeness and suicidal behavior. ${ }^{13}$ (Table 2) 
Tabela 2. Dr Ann McCormack, a staff specialist in endocrinology at St Vincent's Hospital Sydney, She suggested system-wide changes, such as: (https://www.mja.com.au/journal/2018/reducing-risk-suicide-medical-profession)

- Doctors should invest in activities that will support their physical and mental health, and model such behaviour to junior colleagues;

- Doctors need to learn how to be kinder to themselves and extend compassion towards the struggles of both junior and senior colleagues;

- Medical students should be selected not just on academic performance but increasingly sophis-ticated aptitude testing should be used;

- Regular enquiry into the mental health of medical students should be a high priority, and ongo-ing support should be offered;

- Doctors should teach and model resilience;

- Doctor wellbeing programs should be mandated, including peer support networks;

- Workforce planning should avoid the growing bottleneck at the advanced training level; and

- Collegiality should be built back into medical and health workplaces.

They learn early in their training to hold the line, to come across as stoic, to turn up ready for work come what may, and never to admit to their vulnerabilities. Despite the fact that $10-20 \%$ of them have suffered from depression, and suicide rates are reported to be much higher than among other professional groups or the general population, doctors have poor access to mental health care. ${ }^{9}$ The idea of giving up life comes when worries, fatigue, and emotional pain pile up on a level that makes doctors feel incapable of bearing that suffering. It is not out of weakness or cowardice that they deliver the points. Behind the thought that living does not make sense or that it is impossible to regain control of problems, there is a psychic illness. An internal struggle to rediscover the balance, accompanied by a deep anguish that they do not confide even to the people close to them. ${ }^{14}$

In the bustle of emergency care you can feel alone, running from patient to patient; some you can save, some you can't. Pressure to treat patients quickly with compassion when you are terrified of missing something and trying to hide your symptoms is draining. ${ }^{12}$ Their working conditions are more stressful and punishing than anything the rest of us have to deal with in a day at the office. When a junior doctor walked into the sea and drowned in 2016, her parents wrote: "Long hours, work-related anxiety and despair at her future in medicine were definite contributors to this awful and final decision." Only last month, a trainee paediatrician killed herself following a panic attack at work. ${ }^{7}$ The rate of suicide among physicians is $70 \%$ higher than in the general population, according to data from the Regional Council of Medicine of São Paulo. Factors that contribute to this high number are the high professional stress, the fact of dealing with human tragedies and the easy access to medicines. ${ }^{10}$

Suicide itself is already taboo. In the medical class, it's even more so. It is very common for these doctors not to be adequately cared for in the emergency services because there is a certain disrespect for the attempts. Because it is an intentional act, it is as if the person had full freedom from the choice he made. Often, they do not. At the moment she makes the choice, she has a distortion of perception, says Alexandrina Meleiro, PhD in psychiatry at the Institute of Psychiatry at USP (University of São Paulo). ${ }^{14}$
Conventional wisdom has it that medics cauterise their emotions to protect themselves, but the evidence suggests that in fact suppressing their feelings makes them burn out more quickly. ${ }^{11}$ They find it hard to accept that a doctor could have two personae - a strong, powerful medic on the one hand and a frightened and sick individual on the other (The Guardian, 2018c). It is a consensus among experts that information is the best way to staunch suicides and improve the mental health of doctors. ${ }^{14}$

We must allow doctors to become patients without the fear of sanctions or blame, and afford them the same compassion as they are expected to give to their own patients. ${ }^{12}$ Only $1 / 3$ of medical students experiencing burnout seek help often because of self and public stigma associated with seeking help. ${ }^{15}$

Modesto Leite Rolim Neto

https://orcid.org/0000-0001-9379-2120

Nádia Nara Rolim Lima

https://orcid.org/0000-0003-1685-1232

\section{Acknowledgements}

The authors would like to thank the Research Group: Suicidology - Universidade Federal do Ceará (UFC) and Brazilian National Council for Scientific and Technological Development (CNPq) - institution linked to the Brazilian Department of Science, Technology and Scientific Writing Lab, Medicine School Universidade Federal of Cariri (UFCA).

\section{Funding}

The Research Group: Suicidology - Universidade Federal do Ceará (UFC) and Brazilian National Council for Scientific and Technological Development (CNPq) - institution linked to the Brazilian Department of Science, Technology and Innovation to encourage research in Brazil.

\section{Conflict of interests}

The authors declare that they have no competing interests.

\section{Ethical Statement}

We declare that there is no ethical conflict.

All authors agree to send the manuscript for publication. 


\section{References}

1. Jonhson A. Suicide rates for doctors and young physicians among highest in the US population [Internet]. World Socialist Web Site; 2019 [updated 17 June 2019; cited 202116 Aug]. Available from: https://www.wsws.org/en/ articles/2019/06/17/doct-j17.html.

2. Murphy B. How often do physicians and medical students die of suicide? [Internet]. AMA; 2019 [updated 12 June 2019; cited 202116 Aug] Available from: https://www.ama-assn.org/ practice-management/physician-health/howoften-do-physicians-and-medical-students-diesuicide.

3. Gishen F. Suicide among medical students [Internet]. The BMJ Opinion; 2019 [updated 28 Jun 2019; cited 202116 Aug] Available from: https://blogs.bmi.com/bmi/2019/06/28/ faye-gishen-we-need-to-talk-about-young-doctorsmental-health/.

4. Thees $V$. Prevalência de transtornos mentais entre estudantes de medicina pode chegar a 50\%! [Internet]. PEBMED; 2018 [updated 11 Sep 2018; cited 202116 Aug]. Available from: https://pebmed.com.br/prevalencia-detranstornos-mentais-entre-estudantes-de-medicinapode-chegar-a-50/.

5. Nascimento B. Médicos e policiais estão entre profissões que mais sofrem com depressão [Internet]. O Globo; 2017 [updated 12 Feb 2017; cited 202116 Aug]. Available from: https://oglobo.globo.com/economia/medicospoliciais-estao-entre-profissoes-que-mais-sofremcom-depressao-20914781.

6. Thees V. 1 em cada 4 estudantes de medicina sofre de depressão. E o pior: não procuram ajuda! [Internet]. PEBMED; 2016 [updated 10 Dec 2016; cited 202116 Aug]. Available from: https://pebmed.com.br/1-em-cada-4-estudantesde-medicina-sofre-de-depressao-e-o-pior-naoprocuram-ajuda/.

7. By the end of my first year as a doctor, I was ready to kill myself [Internet]. The Guardian; 2018 [updated 5 Jan 2016; cited 202116 Aug]. Available from: https://www.theguardian.com/healthcarenetwork/views-from-the-nhs-frontline/2016/ jan/05/doctor-suicide-hospital-nhs.
8. Vieira B. USP tem $\mathbf{4}$ suicídios em $\mathbf{2}$ meses e cria escritório de saúde mental para alunos [Internet]. Folha de São Paulo; 2018 [updated 1 Aug 2018; cited 202116 Aug] Available from: https:// www 1.folha.vol.com.br/cotidiano/2018/08/ usp-tem-4-suicidios-em-2-meses-e-cria-escritorio-desaude-mental-para-alunos.shtml.

9. Aitkenhead D. Panic, chronic anxiety and burnout: doctors at breaking point [Internet]. The Guardian; 2018 [updated 10 Mar 2018; cited 202116 Aug ]. Available from: https://www.theguardian.com/society/2018/ $\mathrm{mar} / 10 /$ panic-chronic-anxiety-burnout-doctorsbreaking-point.

10. Medicina: por que o suicídio nesse curso é tão comum? [Internet]. 2018 [updated 22 Aug 2018; cited 202116 Aug]. Available from: https:// gl.globo.com/sp/vale-do-paraiba-regiao/ especial-publicitario/quero-bolsa/bolsas-deestudo/noticia/2018/08/22/medicina-por-queo-suicidio-nesse-curso-e-tao-comum.ghtml.

11. Gerada C. For doctors with mental illness, 'help $\mathbf{m e}^{\prime}$ can be the hardest words [Internet]. The Guardian; 2018 [updated 6 Jun 2018; cited 202116 Aug]. Available from: https://www. theguardian.com/commentisfree/2018/jun/06/ doctors-mental-health-problems-taboo.

12. Janaway B. For doctors with depression, A\&E can be especially tough. I should know [Internet]. The Guardian; 2018 [updated 27 Mar 2018; cited 202116 Aug]. Available from: https://www. theguardian.com/healthcare-network/viewsfrom-the-nhs-frontline/2018/mar/27/depressiondoctor-ae-tough-nhs.

13. Swannell C. Reducing risk of suicide in medical profession [Internet]. The Medical Journal of Australia; 2018 [cited 202116 Aug]. Available from: https://www.mia.com.au/journal/2018/ reducing-risk-suicide-medical-profession.

14. Flores R, Tozzi D, Nascimento M, Bertolotto R, Gerab M, Robic S, . . Soares U. Os médicos estão doentes [Internet]. UOL; 2018 [updated 23 Apr; cited 202116 Aug]. Available from: https:// tab.vol.com.br/edicao/medicos-suicidio/.

15. Turner J. Why Do Doctors Kill Themselves? [Internet]. The physician philosopher; 2018 [updated 19 Feb 2018; cited 202116 Aug ]. Available from: https://thephysicianphilosopher. com/why-do-doctors-kill-themselves/. 